\title{
CLIMATE RELATED DISEASES. CURRENT REGIONAL VARIABILITY AND PROJECTIONS TO THE YEAR 2100
}

\author{
Krzysztof BŁaŻejCZYK ${ }^{1}$, JarosŁaw BARANOWSKI ${ }^{1}$, AnNa BŁAŻEJCZYK ${ }^{2}$ \\ ${ }^{1}$ Department of Geoecology and Climatology, Institute of Geography and Spatial Organization, \\ Polish Academy of Sciences, Warszawa, Poland \\ ${ }^{2}$ Bioklimatologia, Laboratory of Bioclimatology and Environmental Ergonomics, Warszawa, Poland
}

Manuscript received: October 09, 2017

Revised version: January 31, 2018

\begin{abstract}
BŁAŻEJCZYK K., BARANOWSKI J., BŁAŻEJCZYK A., 2018. Climate related diseases. Current regional variability and projections to the year 2100. Quaestiones Geographicae 37(1), Bogucki Wydawnictwo Naukowe, Poznań, pp. 23-36. 7 figs, 3 tables.

ABSTRACT: The health of individuals and societies depends on different factors including atmospheric conditions which influence humans in direct and indirect ways. The paper presents regional variability of some climate related diseases (CRD) in Poland: salmonellosis intoxications, Lyme boreliosis, skin cancers (morbidity and mortality), influenza, overcooling deaths, as well as respiratory and circulatory mortality. The research consisted of two stages: 1) statistical modelling basing on past data and 2) projections of CRD for three SRES scenarios of climate change (A1B, A2, B1) to the year 2100. Several simple and multiply regression models were found for the relationships between climate variables and CRD. The models were applied to project future levels of CRD. At the end of $21^{\text {st }}$ century we must expect increase in: circulatory mortality, Lyme boreliosis infections and skin cancer morbidity and mortality. There is also projected decrease in: respiratory mortality, overcooling deaths and influenza infections.
\end{abstract}

KEY WORDS: climate related diseases, Poland, SRES, climate projections, CRD projections

Corresponding author: Krzysztof Błażejczyk,k.blaz@twarda.pan.pl

\section{Introduction}

In spite of great progress in medicine the health of individuals and societies still strongly depends on atmospheric factors which influence humans in direct and indirect ways. The direct impacts are the effects of single climate elements and weather phenomena and the indirect ones influence humans by urbanization, drinking water, vector born diseases and air pollution. All indirect impacts are more or less influenced by climate and weather conditions (Confalonieri et al. 2007).

The exposure to environmental and weather stimuli should be considered in two time perspectives. The short-term impacts of weather could induce subjective ailments in men, intensify some objective symptoms of many illnesses and within the groups of higher risk (elderly, convalescent, small children) they could cause a death. Long-term impacts lead to cumulating in the body negative agents and can cause permanent changes in health status of individuals (Confalonieri et al. 2007, Skotak 2010, Błażejczyk et al. 2015, 2017).

Meteorological factors and general climate features influence human health and wellbeing as weather stimuli (Fers 1995, Kalkstein 1998, McGregor 2001). In low and moderate latitudes the research most frequently refer increase in mortality and morbidity during heat waves (Kuchcik, Błażejczyk 2001, Dessai 2002, Diaz et 
al.2006, Kuchcik 2006) which is an effect of common impacts of air temperature, great insolation and high air humidity (Matzarakis, Mayer 1991, Błażejczyk et al. 1999, 2000, Laschewski, Jendritzky 2002, Błażejczyk 2009). However, in high latitudes low temperatures and strong winds play important role (as so called cold waves) in human morbidity and mortality (Eng, Mercer 1998, Gyllerup 1998, Keatinge, Donaldson 1998).

Many of health problems are caused by specific values of meteorological elements, especially: solar radiation, air temperature and humidity, wind speed and air pressure. In case of solar radiation the special attention should be paid to ultraviolet rays (UV). From the one side they have antibacterial properties, intensify skin burning and help in psoriasis treatment (Jendritzky 1995). However, from the other side intensive UV radiation can cause skin diseases (including skin melanoma) as well as eye illnesses and immunology system disturbances (Lityńska et al. 2001, Lucas et al. 2006, Confalonieri et al. 2007, Błażejczyk, Błażejczyk 2012a).

Air temperature and humidity are weather stimuli which influence human organism continuously. It must adapt to temporal and spatial changes of thermal and humidity stimuli. Thermal adaptation loads circulatory and respiratory systems. In the effect the exposure to strong thermal stimuli reduce effectiveness of such systems and the whole organism. While at young and healthy people it doesn't provoke acute health problems than at elderly and small children it can lead to serious disorders of thermoregulatory and circulatory systems (Improving... 2009).

Direct cause of many health troubles and even deaths are extreme weather phenomena. For example, in the United States most frequent are deaths related to heat waves, floods and strong winds (tornados and hurricanes) (Munich Re 2005). For Poland there are exists only general statistics regarded traffic accidents. According to police statistics in 1998 almost 19\% of accidents were related to worse weather (about 16\% to rain- and snowfalls, $1 \%$ to fog and $2 \%$ to strong winds and intensive insolation) (Kuchcik 2001, Kozłowska-Szczęsna et al. 2004).

Some health troubles are indirectly associated with climatic factors through urbanisation, air and water pollution, food poisoning and vector born infections (Kovats et al. 2004). For example Kuchcik (2001) reported increased number of diseases related to common effect of heat and air pollution. Also in EuroHEAT project the researchers observed in 9 European cities 16\% increased of deaths during hot days with elevated level of tropospheric ozone concentration (hot conditions alone caused $10 \%$ increase in mortality). However, increased concentration of PM10 caused $4 \%$ rise in mortality risk (Improving... 2009).

High air temperature accelerates multiplication of pathogens in food and water (Skotak 2010). For example in elevated air temperatures we observe good conditions for gradation of Salmonella bacteria in food and summer peak of salmonellosis intoxication is observed (Błażejczyk et al. 2011, Błażejczyk, Błażejczyk 2012b).

Weather conditions influence also number and activity of parasites which are the vectors for different pathogens (Błażejczyk 2009). In Poland and in whole central Europe the most frequent are Lyme boreliosis infections distributed by ticks (Ixodes ricinus). Lingren and Jeansen (2006) reported increased number of Lyme boreliosis infections not only in central Europe but also in Scandinavia which is an effect of warming climate.

Research dealing with the influence of climate on human health are carried out in many centres all over the world. The Table 1 gives the list of only selected research related to climate impacts on human health. Recently there were finished the project supported by the Polish National Centre for Research (NCN) No. 2011/01/B/ ST10/06972 "Assessment of climate change impacts on population health in various regions of Poland, and projections to the year 2100". The essential results of the project were published by Błażejczyk et al. (2015) ${ }^{1}$. The research carried out in the cited project gave current regional variability of CRD in Poland and predictions of their spatial distribution to the end of $21^{\text {st }}$ century.

Research dealing with the assessment of possible impacts of climate change on human health in local and global scales were also conducted by Haines et al. (2006), Gosling et al. (2007, 2009), Ebi

The project considered also changes in heat and cold related mortality in Poland and the results of such studies were published by Błażejczyk et al. (2017). 
Table 1. Ecological and health effects of climate elements

\begin{tabular}{|c|c|c|c|c|}
\hline Climate element & Measure & Ecological effects & Health effects & Selected references \\
\hline \multirow[t]{2}{*}{ Solar radiation } & UV increase & $\begin{array}{l}\text { Destruction of living } \\
\text { cells }\end{array}$ & Increase in skin cancer & $\begin{array}{l}\text { Lityńska et al. 2001, Lucas et } \\
\text { al. 2006, Błażejczyk, Błażejczyk } \\
\text { 2012b }\end{array}$ \\
\hline & Insolation & No data & $\begin{array}{l}\text { Solar stroke } \\
\text { Road accidents }\end{array}$ & $\begin{array}{l}\text { Jendritzky 1995, Błażejczyk et } \\
\text { al. } 1999\end{array}$ \\
\hline \multirow[t]{4}{*}{ Air temperature } & Heat waves & $\begin{array}{l}\text { Increase in tropo- } \\
\text { spheric ozone con- } \\
\text { centration }\end{array}$ & $\begin{array}{l}\text { Increase in mortality } \\
\text { Heat stroke } \\
\text { Dehydration } \\
\text { Asthma }\end{array}$ & $\begin{array}{l}\text { Desai 2002, Kuchcik 2003, , Diaz } \\
\text { et al. 2006, d'Ipoliti et al. 2010, } \\
\text { Baccini et al. 2011, }\end{array}$ \\
\hline & Cold waves & $\begin{array}{l}\text { Increase in PM10 and } \\
\mathrm{SO}_{2}\end{array}$ & $\begin{array}{l}\text { Overcooling } \\
\text { Respiratory system } \\
\text { Accidents } \\
\text { Asthma }\end{array}$ & $\begin{array}{l}\text { Donaldson, Keatinge 1997, Eu- } \\
\text { rowinter Group 1997, Gyllerup } \\
\text { 1998, Eng, Mercer 1998, Analitis } \\
\text { et al. } 2008\end{array}$ \\
\hline & Hot summers & $\begin{array}{l}\text { Ticks gradation } \\
\text { Water pollution }\end{array}$ & $\begin{array}{l}\text { Digestive intoxications } \\
\text { Vector born diseases }\end{array}$ & $\begin{array}{l}\text { Błażejczyk \& McGregor 2008, } \\
\text { Błażejczyk 2009, Michelozzi et } \\
\text { al. 2009, Błażejczyk, Błażejczyk } \\
\text { 2012a }\end{array}$ \\
\hline & Warm winters & $\begin{array}{l}\text { Early flowering and } \\
\text { pollens }\end{array}$ & $\begin{array}{l}\text { Increase in allergies } \\
\text { and asthma } \\
\text { Early boreliosis infec- } \\
\text { tions }\end{array}$ & $\begin{array}{l}\text { Siuda 1993, Kiewra et al. 2004, } \\
\text { Lindgren, Jaenson } 2006\end{array}$ \\
\hline \multirow[t]{2}{*}{ Precipitation } & Heavy rains & $\begin{array}{l}\text { Flooding, pollution } \\
\text { of drinking water, } \\
\text { bad road conditions }\end{array}$ & $\begin{array}{l}\text { Digestive intoxication } \\
\text { Drownings } \\
\text { Road accidents }\end{array}$ & $\begin{array}{l}\text { Mączyński 1972, Kuchcik } \\
\text { 1998, Confalonieri et al. 2007, } \\
\text { Błażejczyk 2009, Skotak 2010, } \\
\text { Błażejczyk, Błażejczyk 2012b }\end{array}$ \\
\hline & Droughts & $\begin{array}{l}\text { Air pollution, Aller- } \\
\text { gens }\end{array}$ & $\begin{array}{l}\text { Asthma } \\
\text { Allergies }\end{array}$ & $\begin{array}{l}\text { Małolepszy 1996, Peternel et al. } \\
2004\end{array}$ \\
\hline \multirow[t]{2}{*}{ Wind } & Calms & Air pollution increase & $\begin{array}{l}\text { Asthma } \\
\text { Respiratory system } \\
\text { disorders }\end{array}$ & $\begin{array}{l}\text { Thompson et al. 1996, Samo- } \\
\text { liński et al. 2009, }\end{array}$ \\
\hline & Strong winds & $\begin{array}{l}\text { Destruction of build- } \\
\text { ing and trees }\end{array}$ & $\begin{array}{l}\text { Fatal accidents } \\
\text { Nervous system trou- } \\
\text { bles }\end{array}$ & $\begin{array}{l}\text { Keatinge, Donaldson 1998, } \\
\text { Keatinge } 2002\end{array}$ \\
\hline Air pressure & $\begin{array}{l}\text { Extreme pres- } \\
\text { sure } \\
\text { Changes in } \\
\text { pressure }\end{array}$ & No data & $\begin{array}{l}\text { Circulatory system } \\
\text { and nervous system } \\
\text { disorders }\end{array}$ & $\begin{array}{l}\text { Huszcza 1951, Kozłowska- } \\
\text {-Szczęsna et al. } 2004\end{array}$ \\
\hline
\end{tabular}

(2008, 2015), Åström et al. (2013, 2015), Braks et al. (2014), Grillakis et al. (2016), Pappenberger et al. (2014), Peterson et al. (2014) and others.

The aim of the paper is to present spatial distribution of selected climate related diseases (CRD) in Poland. The attention is paid for both, the current situation and projections to the year 2100 .

\section{Data and Methods}

The research consisted of two stages:

- statistical modelling basing on the past data (climatological and epidemiological) for the longest available period and
- projections of CRD for three climate change SRES scenarios (A1B, A2, B1) to the year 2100 (Fig. 1).

Epidemiological data were adapted from national and European statistical databases. The following climate related diseases were taking into consideration: salmonellosis intoxications (period 1999-2014), Lyme boreliosis (19962014), skin cancers (morbidity - 1999-2012 and mortality 1973-2012), influenza (1973-2012), overcooling deaths (1990-2014), mortality caused by dysfunctions of respiratory and circulatory systems (1973-2012). For the most of diseases the data have regional resolution (at the voivodeship level). For overcooling deaths 

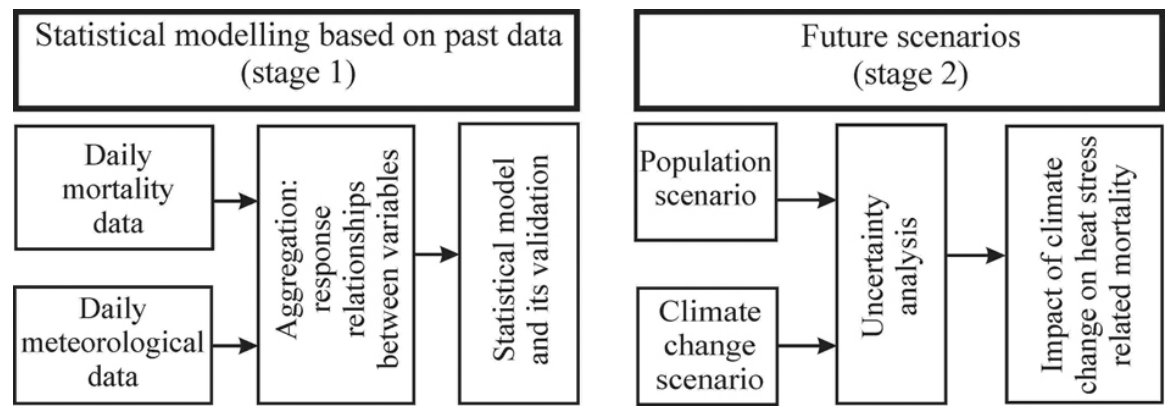

Fig. 1. Scheme of research (adapted from Gosling et al. 2007).

as well as circulatory and respiratory mortality the data represent the whole country. We have consider both, absolute number of cases and relative health indicators (number of cases per 100000 inhabitants).

Climatological data base consists of daily values of air temperature (mean, maximum and minimum) and humidity, wind speed and precipitation for the period 1973-2014, taken from NOAA database for 26 meteorological stations in Poland (Białystok, Bielsko Biała, Elbląg, Gdańsk Rembiechowo, Gorzów Wielkopolski, Katowice Pyrzowice, Kielce, Koszalin, Kraków Balice, Lesko, Lublin Radawiec, Łódź Lublinek, Olsztyn, Opole, Poznań Ławica, Pszczyna, Rzeszów Jasionka, Siedlce, Suwałki, Szczecin Dąbie, Świnoujście, Tarnów, Torun, Warszawa Okęcie, Wrocław Strachowice, Zielona Góra). To find statistical relationships between meteorological variables and health indicators we have applied average spatial values of several climate indicators: mean air temperature (Tavg, $\left.{ }^{\circ} \mathrm{C}\right)$, mean and absolute minimum (Tmin, ${ }^{\circ} \mathrm{C}$ ) and maximum $\left(\operatorname{Tmax},{ }^{\circ} \mathrm{C}\right.$ ) air temperature, number of days with Tmax $<0^{\circ} \mathrm{C}$, number of days with Tmax $>25^{\circ} \mathrm{C}$, number of days with $\mathrm{Tmin}<-10^{\circ} \mathrm{C}$, precipitation totals $(\mathrm{mm})$, number of days with precipitation, number of days with wind $>8 \mathrm{~m} / \mathrm{s}$ and number of days with wind $\leq 1 \mathrm{~m} / \mathrm{s}$. Particular climate characteristics were calculated for several periods: months, seasons (summer and winter), year, warm period (May-September) and cold period (November-March).

At the final phase of the first stage of research the models which describe influence of climate on some diseases were searched. The models were developed by statistical relationships between climate variables and standardised mortality as well as morbidity rates. Simple and multiply regression models were found. The statistical analysis were made with the use of STATGRAPHICS 7.2. software package.

The projections of climate variables were adapted from METEONORM 7 software package. It generates set of variables for consecutive decades of $21^{\text {st }}$ century using the average values of climate elements obtained from 18 climate models as a part of $4^{\text {th }}$ assessment report of IPCC (Meehl et al. 2007). The simulations were made for three different $\mathrm{CO}_{2}$ emission scenarios: $\mathrm{B} 1$ (low), A1B (average) and A2 (high) (Nakićenović et al. 2003). In the projection phase of research the same set of climate variables as for historical data was used. Additionally, summer totals of global solar radiation were calculated

In the second stage of research the regression equations founded for historical data were used for the projections of future morbidity and mortality rates of CRD. For the particular decades of $21^{\text {st }}$ century there were calculated standardised morbidity and mortality rates per 100000 inhabitants as well as changes in these rates in relation to their currently observed values. There were also assessed absolute amount of overcooling death cases. The calculations were made with the voivodship spatial resolution.

\section{Results}

\section{Evidence of CRD and climate variables}

During the studied period fluctuations and changes in CRD were observed. Great increase was found for: Lyme boreliosis infections (from 10 in 1996 to 35 per 100000 in 2014), skin cancer morbidity (from 17 in 1999 to about 30 per 100000 in 2012) and melanoma deaths (from about 0.6 in 1970 to 3.5 in 2012). Respiratory mortality is slightly rising during last 20 years (from 
30 in 1993 to 55 per 100000 in 2012). However, the level of circulatory mortality decreased in the last 20 years (from about 520 in 1990 to 450 per 100000 in 2012).

For the other CRD we have observed temporal fluctuations in the studied period. The greatest amount of salmonellosis intoxications was noted in the periods 1985-1990 and 1995-2000. Last 15 years bring gradual decrease in salmonellosis cases from 78 in 1995 to about 22 per 100000 in 2014. The number of influenza cases over the years 1960-2009 was diversified and changes from less than 100 thousands in 1990 to over 6
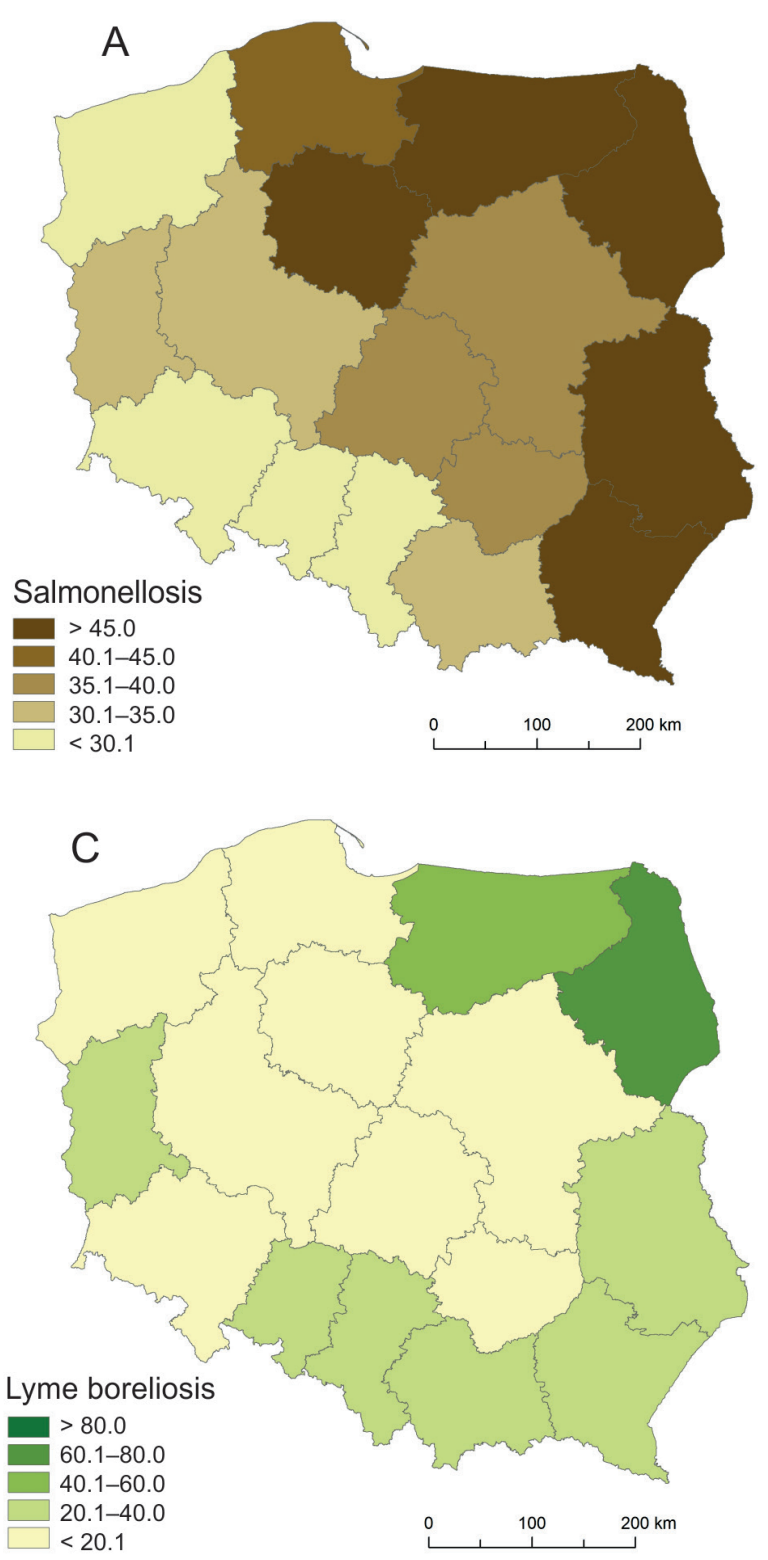

million in 1971. The number of cold wave victims ranges from 50 in 1997 to almost 300 in 2009.

Considering spatial variability of CRD there is seen significant regional differentiation. The great number of salmonellosis intoxications is observed in eastern and north-eastern voivodships as well as in Kujawy region (>45 cases per 100000 inhabitants, Fig. 2A). Influenza infections are the most frequent in central part of Poland as well as in Małopolskie and Pomorskie voivodships (>3000 cases per 100 000, Fig. 2B). For the vector borne diseases (Lyme boreliosis, tick born viral encephalitis) are the most exposed population
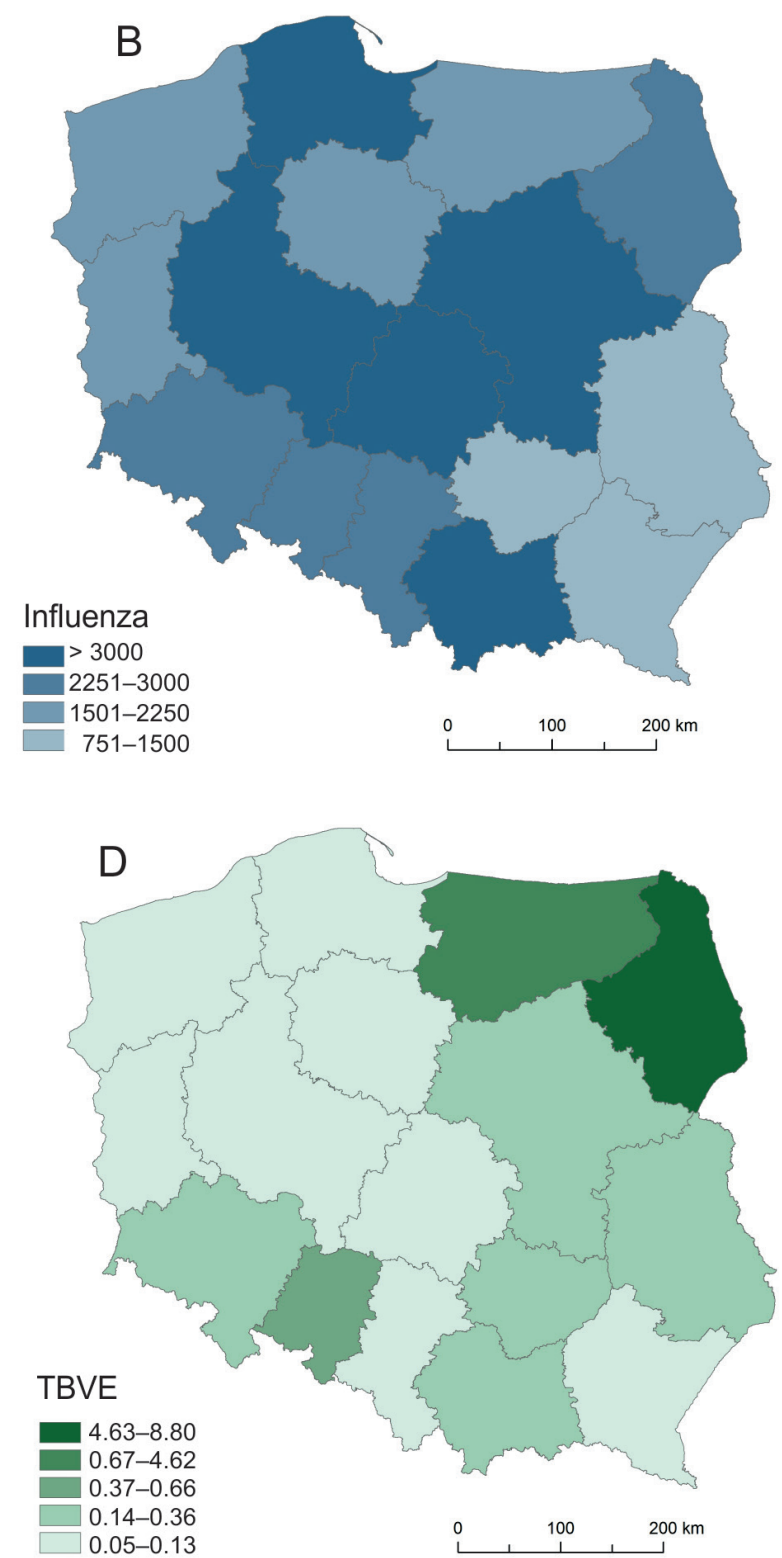

Fig. 2. Mean yearly number (per 100000 inhabitants) of selected CRD: A - salmonellosis intoxication (19992014), B - influenza infections (1973-2014), C - Lyme boreliosis (2003-2014), D - tick born viral encephalitis

(TBVE, 1999-2014). 

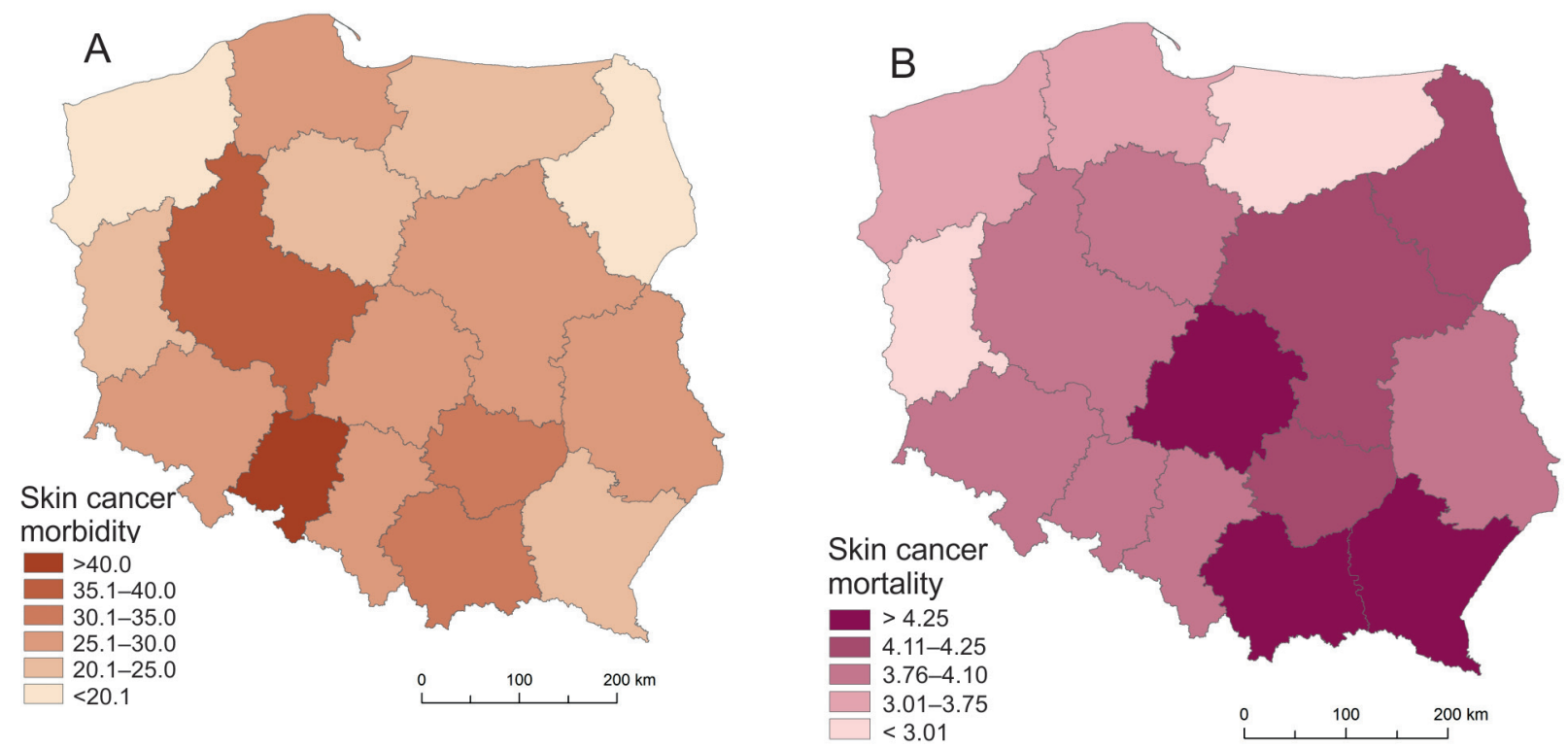

Fig. 3. Mean yearly number (per 100000 inhabitants, 1999-2012) of skin cancers morbidity (A) and mortality (B).

of Podlaskie and Warmińsko-mazurskie voivodships (respectively, > 80 and 4.62 infections per 100 000, Fig. 2C, 2D).

The spatial picture of skin cancer morbidity shows that the greatest risk of any cancer is observed in Wielkopolskie and Opolskie voivodeships (>40 cases per 100000 inhabitants, Fig. 3A). However, the greatest cancer mortality $(>4.25$ cases per 100000 ) was found in Łódzkie, Małopolskie and Podkarpackie voivodeships (Fig. 3B).

In case of skin melanoma, which is the most aggressive form of skin cancer, its the greatest rate of morbidity ( $>6.15$ per 100000 inhabitants)

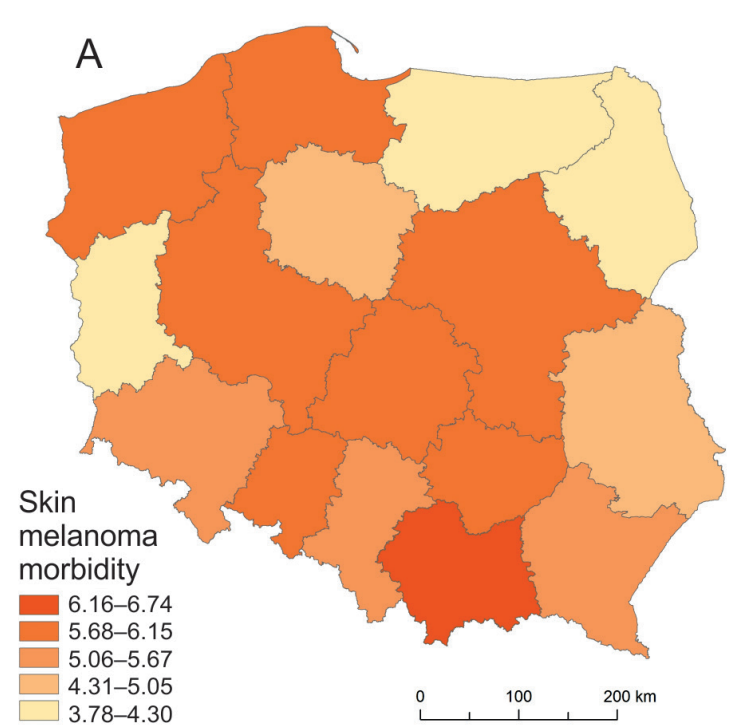

was found in Małopolskie voivodships (Fig. 4A). However, the deaths caused by skin melanoma are the most frequent $(>2.83$ cases per 100000$)$ in several voivodships in different parts of Poland: Dolnośląskie, Małopolskie, Podkarpackie and Mazowieckie (Fig. 4B).

\section{Indicators of climate impacts on climate related diseases}

The yearly standardised numbers of particular CRD were compared with climate variables. Various sets of climate variables were analysed

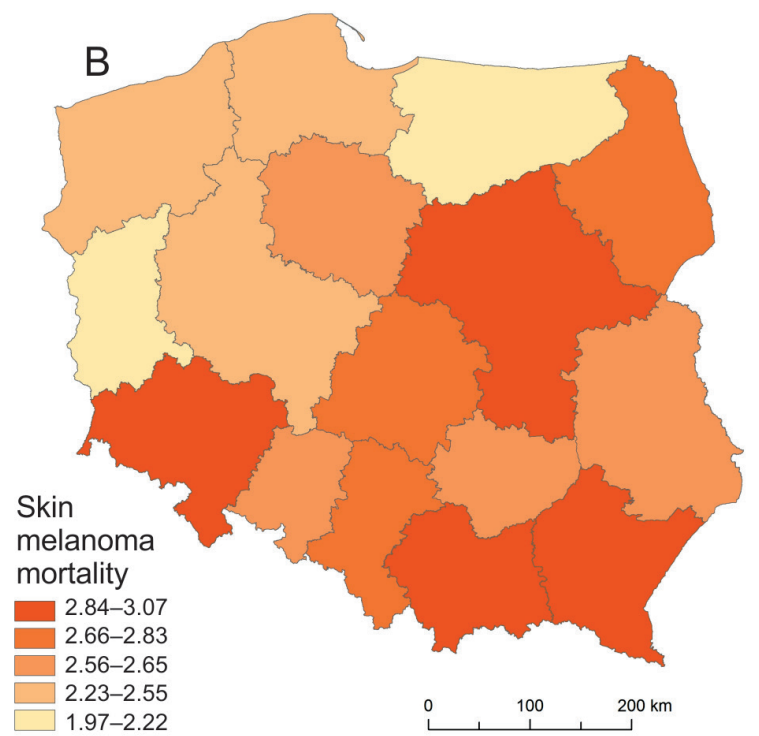

Fig. 4. Mean yearly number (per 100000 inhabitants, 1999-2012) of skin melanoma morbidity (A) and mortality (B). 
Table 2. Regression models of climate related mortality and morbidity.

\begin{tabular}{|c|c|c|c|}
\hline Regression model & $\begin{array}{l}\text { Mean abso- } \\
\text { lute error }\end{array}$ & $\begin{array}{l}\text { Determination } \\
\text { coefficient }(\%)\end{array}$ & $\begin{array}{c}\text { Confidence } \\
\text { level }(\%)\end{array}$ \\
\hline \multicolumn{4}{|l|}{ Skin cancer morbidity / 100000} \\
\hline$-60.8+0.05311 \cdot$ Kglob_summer & 2.83 & 54.88 & 95 \\
\hline \multicolumn{4}{|l|}{ Skin cancer mortality / 100000} \\
\hline $1.3+0.001597 \cdot$ Kglob_summer & 0.102 & 39.07 & 95 \\
\hline \multicolumn{4}{|c|}{ Lyme boreliosis morbidity / 100000} \\
\hline $\begin{array}{l}-59.1+3.71 \text { Tmin_avg_XI-III + } 0.046 \cdot \text { Prec_totals V-IX + 3.25 Tmax_ } \\
\text { avg_V-IX }\end{array}$ & 5.39 & 40.96 & 85 \\
\hline \multicolumn{4}{|l|}{ Salmonellosis intoxications / 100000} \\
\hline $\begin{array}{l}\text {-307.8 - 9.42 Tmin_avg_summer }-1.9 \cdot \text { Tmax }>25 \text { Tsummer }+29.4 \cdot \text { Tavg_ } \\
\text { summer - } 6.6 \cdot \text { Tmax_avg_summer }+4.9 \cdot \text { Tmax_summer }\end{array}$ & 13.46 & 30.59 & 95 \\
\hline \multicolumn{4}{|l|}{ Influenza morbidity / 100000} \\
\hline $\begin{array}{l}18178.5-1598.9 \cdot \text { Tavg_winter }-12.3 \cdot \text { Tmax }<0 \text { _winter + } 1807.2 \cdot \text { Tmin_avg_ } \\
\text { winter }-1799.7 \cdot \text { Tmax_avg_winter }\end{array}$ & 2094.56 & 25.42 & 95 \\
\hline \multicolumn{4}{|l|}{ Circulatory mortality / 100000} \\
\hline $\begin{array}{l}325.6+4.2 \cdot \operatorname{Tmin}<-10-1.6 \cdot \operatorname{Tmax}>25-2.1 \text { Sultry }+12.9 \cdot \text { Tmin_avg }- \\
93.3 \cdot \text { Tmax_avg }+143.9 \cdot \operatorname{Tavg}\end{array}$ & 49.57 & 22.79 & 85 \\
\hline \multicolumn{4}{|l|}{ Respiratory mortality / 100000} \\
\hline $\begin{array}{l}72.1-45.0 \cdot \text { Tśr_winter }+17.4 \cdot \text { Tmax_avg_winter }-1.1 \cdot \text { Tavg }+21.7 \cdot \text { Tmin } \\
\text { avg_winter }-0.5 \cdot \operatorname{Tmax}<0+0.044 \cdot \text { Tmin }<-10+1.0 \cdot \mathrm{v}>8 \text { _winter }\end{array}$ & 4.26 & 48.10 & 95 \\
\hline \multicolumn{4}{|l|}{ Overcooling deaths } \\
\hline $183.0+13.2 \cdot$ Tmin_winter $-3.8 \cdot T m i n \_a v g \_w i n t e r$ & 72.34 & 24.48 & 90 \\
\hline
\end{tabular}

Kglob_summer - summer totals of global solar radiation $\left(\mathrm{MJ} / \mathrm{m}^{2}\right)$,

Tavg - mean yearly air temperature $\left({ }^{\circ} \mathrm{C}\right)$,

Tavg_summer, Tavg_winter - mean air temperature for summer and winter periods $\left({ }^{\circ} \mathrm{C}\right)$,

Tmin_avg - mean yearly minimum air temperature $\left({ }^{\circ} \mathrm{C}\right)$,

Tmin_avg_summer, Tmin_avg_winter, Tmin_avg_V-IX, Tmin_avg_XI-III - mean minimum air temperature for particular periods $\left({ }^{\circ} \mathrm{C}\right)$,

Tmax_avg - mean yearly maximum air temperature $\left({ }^{\circ} \mathrm{C}\right)$,

Tmax_avg_summer, Tmax_avg_winter, Tmax_avg_V-IX, Tmax_śr_XI-III - mean maximum air temperature for particular periods $\left({ }^{\circ} \mathrm{C}\right)$,

Tmin - lowest yearly minimum air temperature $\left({ }^{\circ} \mathrm{C}\right)$,

Tmin_summer, Tmin_winter, Tmin_V-IX, Tmin_XI-III - lowest minimum air temperature for particular periods $\left({ }^{\circ} \mathrm{C}\right)$,

Tmax - highest yearly maximum air temperature $\left({ }^{\circ} \mathrm{C}\right)$,

Tmax_summer, Tmax_winter, Tmax_V-IX, Tmax_XI-III - highest maximum air temperature for particular periods $\left({ }^{\circ} \mathrm{C}\right)$,

Tmax $<0$ - annual number of days with maximum air temperature $<0^{\circ} \mathrm{C}$,

Tmax $>25$ - annual number of days with maximum air temperature $>25^{\circ} \mathrm{C}$,

Tmax $>25$ _summer - summer number of days with maximum air temperature $>25^{\circ} \mathrm{C}$,

Tmin $<-10$ - annual number of days with minimum air temperature $<-10{ }^{\circ} \mathrm{C}$,

Sultry - annual number of sultry days,

Prec_totals_V-IX - precipitation totals for period ( $\mathrm{mm}$ ),

$\mathrm{v}>8$ _winter - number of windy days in winter.

to find the best fitting of regression line. For each CRD we have studied statistical relationships using both, simple and multiply regression analysis. The best fitted regression equation were considered as indicators which describe influence of climate on CRD (Table 2). Determination coefficients (d) show which percentage of CRD can be explained by the values of applied climate indicators. The greatest $\mathrm{d}$ values were found for skin cancer morbidity $(54.9 \%)$, respiratory mortality $(48.1 \%)$ and Lyme boreliosis infections (41.0\%). Majority of regression equations are true at $95 \%$ confidence level. Only in three cases (overcooling deaths, Lyme boreliosis infections and circulatory mortality) the confidence levels are lower (90 and $85 \%)$.

\section{Projected changes of climate variations}

In general, for central Europe climate models project slight increase of global solar radiation up to about $4 \%$ at the end of $21^{\text {st }}$ century and the differences between SRES scenarios are insignificant. Considerably greater are forecasted changes 
in air temperature. Depending on climate scenario the level of this variable can reach at the end of century up to $11.7^{\circ} \mathrm{C}$ (at A2 scenario), with relative increase of $1.1-2.5^{\circ} \mathrm{C}$. We also must expect increase the number of days with great heat stress (assessed with the use of UTCI index) up to 15\% frequency due to A2 scenario. Projected changes in wind speed are rather insignificant. However, precipitation totals and number of days with precipitation will vary depending on SRES scenario, from slight decrease (at A2 scenario) to significant increase (due to B1 scenario) (Fig. 5).

\section{Projections of population health}

For the projections of morbidity and mortality rates of CRD the regression equations presented in Table 2 were used. It was assumed that relations founded for the whole Poland are represented also for particular voivodships and the projected levels of health indicators will depend on regional differentiations of climate variables. For particular decades of $21^{\text {st }}$ century there were calculated both, CRD mobidity nad mortality rates per 100000 inhabitants and absolute amounts of overcooling deaths. In this purpose the population projection, prepared in the frame
Table 3. Projected changes of the indicators of climate related diseases in Poland for the years 2081-2100.

\begin{tabular}{|l|c|c|}
\hline \multicolumn{1}{|c|}{ Health indicator } & Tendency & $\begin{array}{c}\text { Confidence } \\
\text { of projections }\end{array}$ \\
\hline Skin cancer morbidity & $9-10 \%$ increase & great \\
\hline Skin cancer mortality & $2-3 \%$ increase & great \\
\hline $\begin{array}{l}\text { Lyme boreliosis } \\
\text { infections }\end{array}$ & $22-68 \%$ increase & great \\
\hline Circulatory mortality & $3-4 \%$ increase & moderate \\
\hline $\begin{array}{l}\text { Salmonellosis intoxi- } \\
\text { cations }\end{array}$ & $1-3 \%$ increase & small \\
\hline Respiratory mortality & $7-17 \%$ decrease & great \\
\hline Overcooling deaths & $23-50 \%$ decrease & moderate \\
\hline Influenza infections & $23-68 \%$ decrease & moderate \\
\hline
\end{tabular}

of KLIMADA project, was applies. Such projection assumes that population of Poland will fall from 38.3 million in 2010 to 28.7 million in 2100 ( $25 \%$ decrease).

At the end of $21^{\text {st }}$ century due to predicted climate change we should expect changes in CRD levels. Depending on climatic factors influencing CRD the changes can have positive or negative character. We must expect increase in: circulatory mortality, Lyme boreliosis infections and skin cancer morbidity and mortality. However, there is also projected decrease in: respiratory mortality, influenza morbidity and overcooling mortality
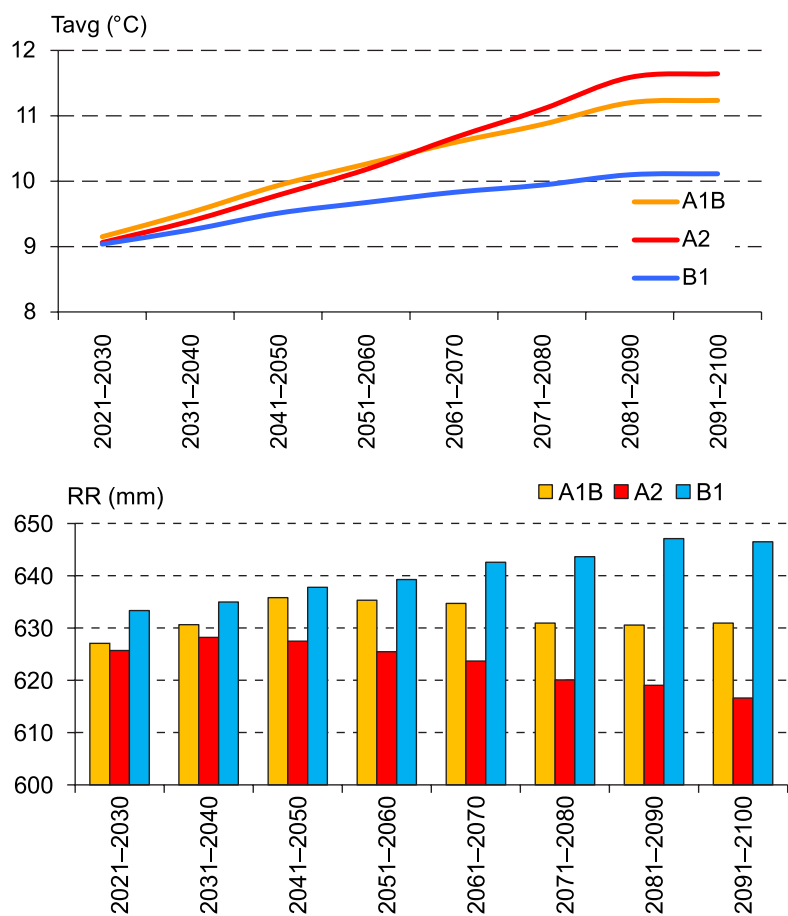
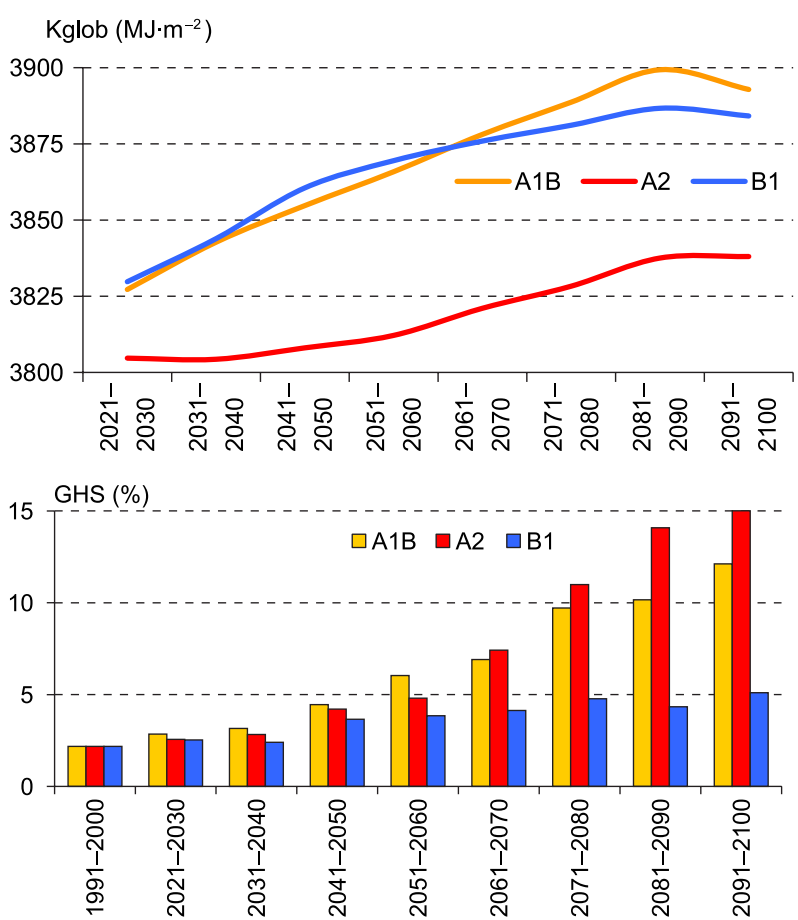

Fig. 5. Projected changes of yearly totals of global solar radiation (Kglob), mean yearly air temperature (Tavg), percentage of days with great heat stress (GHS) and precipitation totals (RR) in consecutive decades of $21^{\text {st }}$ century due to A1B, A2 and B1 SRES scenarios. 

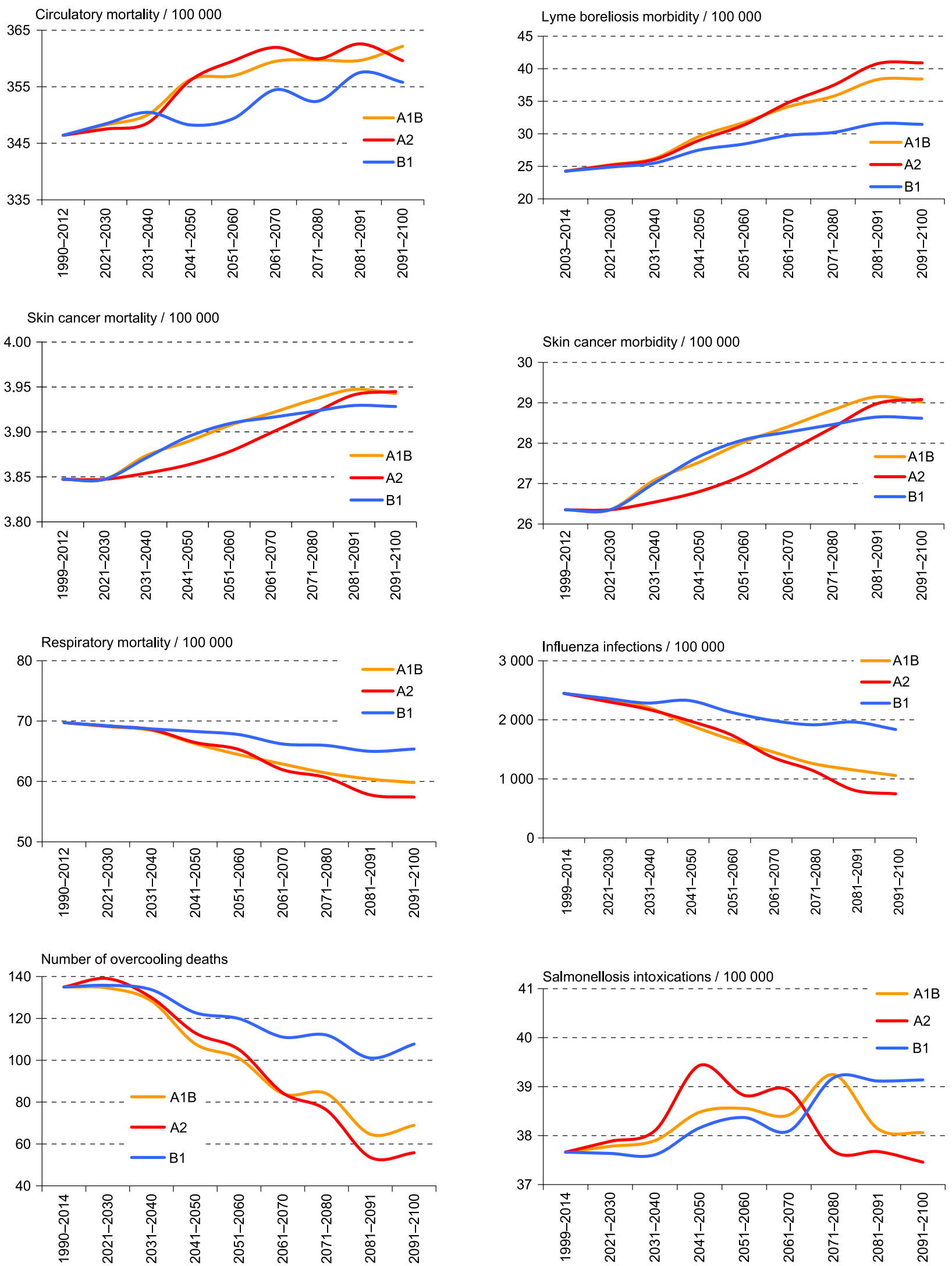

Fig. 6. Projected, for the consecutive decades of $21^{\text {st }}$ century, CRD indicators: circulatory mortality, Lyme boreliosis infections, skin cancer mortality, skin cancer morbidity, respiratory mortality, influenza morbidity, overcooling deaths, salmonellosis intoxications. 

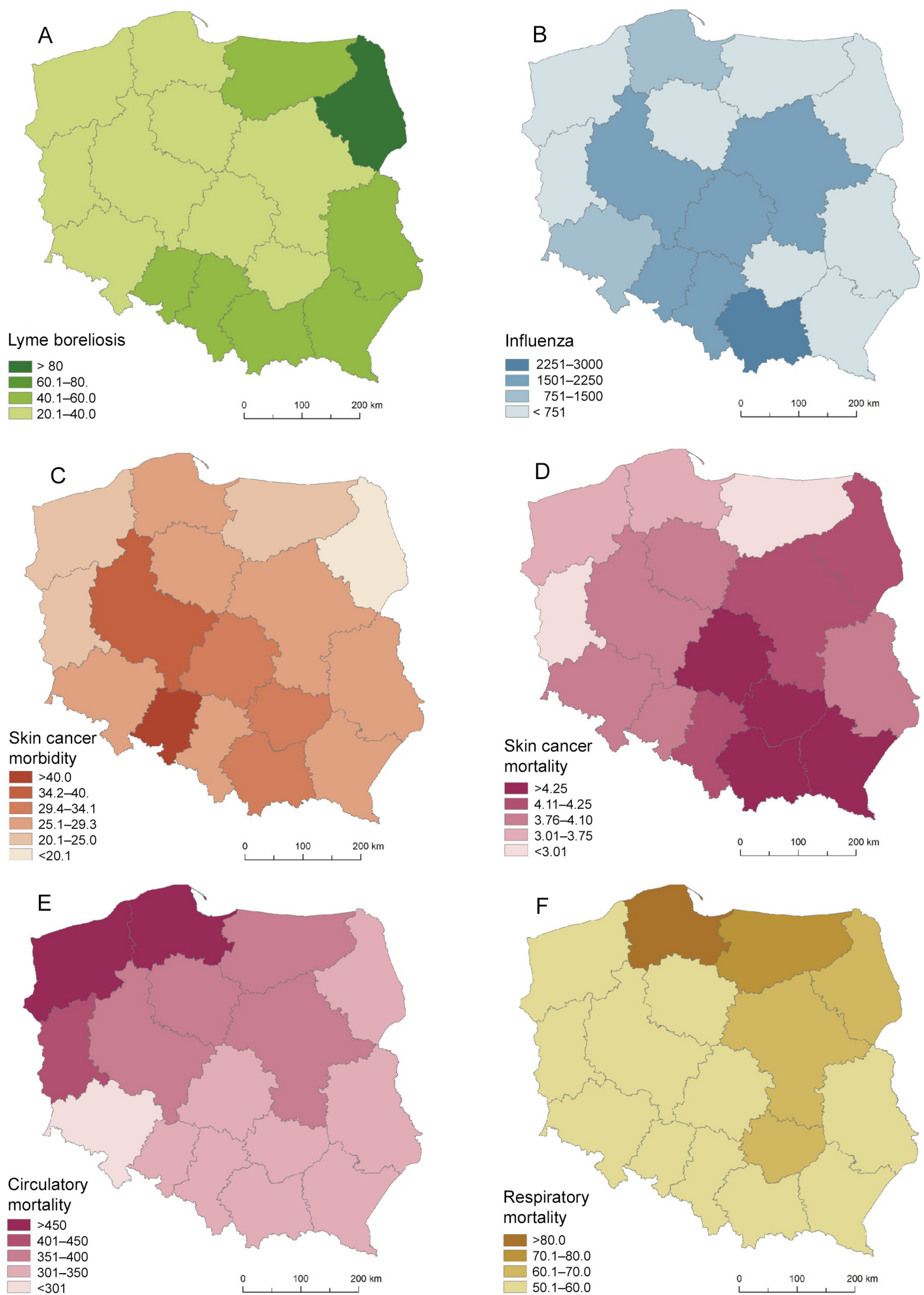

Fig. 7. Spatial distribution of projected risks (per 100000 inhabitants) of selected CRD at the last decade of $21^{\text {st }}$ century due to A1B SRES scenario, A - Lyme boreliosis, B - influenza, C - skin cancer morbidity, D - skin cancer mortality, E - circulatory mortality, F - respiratory mortality. 
and. In salmonellosis intoxications projections show slight fluctuations during $21^{\text {st }}$ century without any clear tendencies (Fig. 6).

Table 3 summarise projected tendencies of changes in CRD at the end of $21^{\text {st }}$ century in relations to the years 2001-2010. At majority of CRD the confidence levels of projected changes can be assessed as great or moderate. Only for salmonellosis intoxications the confidence of projections is small.

To illustrate spatial distribution of projected changes in CRD the maps for considered SRES scenarios were developed. In the present paper maps for A1B scenario (moderate climate change) are shown. In general, spatial distribution of CRD is similar to this found for historical data. Lyme boreliosis will be still most frequent in Podlaskie and Warmińsko-mazurskie voivodships (Fig. 7A). In case of influenza infections citizens of Małopolskie voivodship will be at the greatest risk (Fig. 7B). Skin cancers morbidity will be at the greatest in Opolskie and Wielkopolskie voivodships (Fig. 7C). Slight changes in spatial distribution will occur in case of skin cancer mortality (Fig. 7D). At the end of $21^{\text {st }}$ century the population of Pomorskie, Zachodniopomorskie and Lubuskie voivodships will be mostly exposed to circulatory mortality risk (Fig. 7E). However the greatest risk of respiratory mortality is observed in Pomorskie and Warmińsko-mazurskie voivodship (Fig. 7F).

\section{Conclusions}

The results of research show that we must expect to the end of $21^{\text {st }}$ century significant changes in climate variables and in corresponding CRD. The healthcare system (HCS) in Poland must thus make far-reaching adaptations to anticipated climate change. All the changes in heat stress, population health and adaptation strategies effects must be monitored to ensure expected reduction in the numbers of deaths that would otherwise occur, most especially among the elderly in society.

The principal document which deal with this issue is the National Health Programme (NHP) for years 2016-2020 which was adopted by the Council of Ministers on 4 August 2016. The strategic goal of NHP is to improve health status of the population and to enhance health-related quality of life. The results of research dealing with observed and projected changes in CRD were presented to healthcare authorities (Ministry of Health, national coordinators of treatment procedures) and practitioners (physicians, selected hospital administration, researchers) together with proposed adaptation strategies (Błażejczyk et al. 2015). After several discussions there was developed the catalogue of adaptation strategies of healthcare system (HCS). There were assumed that developed adaptation strategies must be considered in two time perspectives: short term (urgent actions) and long term (permanent actions).

As short-term adaptation actions we can list:

- to equip hospitals, outpatient surgeries and other HCS objects in air conditioning and refrigerating units,

- to prepare medical staff for urgent weather related accidents including heat and cold stress,

- to store sufficient amount of seasonal supply materials (e.g. ice, gypsum etc),

- adequate protection of work places exposed to climate factors (including heat waves) to minimize their negative effects.

The long-term, permanent actions will consist of:

- watch warning system informing society and healthcare authorities of extreme weather events which can cause accidents or health problems,

- periodical courses improving skills of medical personnel for diagnosis and treatment of CRD,

- implementation of educational programs dealing with influences of climate and environmental pollutions on human health,

- organization of laboratories of early diagnosis of tick borne diseases,

- modernization of laboratories of early diagnosis of circulatory disorders,

- improvement of infrastructure in hospitals, outpatients surgeries, health resorts and other objects of healthcare system,

- promotion and prophylactic of the quality of drinking water and food,

- improvement of air quality (developing mechanisms reducing emission of pollutants),

- interactive system for monitoring and registration of CRD,

- founds for scientific research in epidemiology, toxicology and climate physiology leading to better knowledge of CRD mechanisms, 
- informational system in health prophylactic, including periodical health examination, promotion of healthy nutrition and life style, pre-medical aid and appropriate reactions for extreme weather events.

\section{Acknowledgments}

The research presented was supported by Grant from the Polish National Centre for Research (NCN) No. 2011/01/B/ST10/06972 "Assessment of climate change impacts on population health in various regions of Poland, and predictions to the year $2100^{\prime \prime}$

\section{References}

Analitis A., Katsouyanni K., Biggeri A., Baccini M., Forsberg B., Bisanti L., Kirchmayer U., Ballester F., Cadum E., Goodman P.G., Hojs A., Sunyer J., Tittanen P., Michelozzi P., 2008. Effects of cold weather on mortality: results from 15 European Cities within the PHEWE project. American Journal of Epidemiology, 168(12): 1397-1408.

Åström C., Orru H., Rocklöv J., Strandberg G., Ebi K.L., Forsberg B., 2013. Heat-related respiratory hospital admissions in Europe in a changing climate: a health impact assessment. BMJ Open 2013, 3:e001842. doi 10.1136/bmjopen-2012-001842.

Åström C., Ebi K.L., Langner J., Forsberg B., 2015. Developing a Heatwave Early Warning System for Sweden: Evaluating Sensitivity of Different Epidemiological Modelling Approaches to Forecast Temperatures. Int J Environ Res Public Health 12: 254-267. doi 10.3390/ijerph120100254.

Baccini M., Kosatsky T., Analitis A., Anderson H.R., d'Ovidio M., Menne B., Michelozzi P., Biggeri A., Accetta G., de Sario M., d'Ippoliti D., Marino C., Katsouyanni K., Ballester F., Bisanti L., Cadum E., Forsberg B., Forastiere F., Goodman P.G., Hojs A., Kirchmayer U., Medina S., Paldy A., Schindler C., Sunyer J., Perucci C.A., McGregor G., Kassomenos P., Atkinson R., Medina S., Clancy L., Pekkanen J., Woityniak B., Jolliffe I., Jendritzky G., Blazejczyk K., Huth R., Cegnar T., Iniguez C., Monceau G., Kalkstein L.S., 2011. Impact of heat on mortality in 15 European cities: attributable deaths under different weather scenarios. J Epidemiol Comm Health 65(1): 64-70. doi: 10.1136/jech.2008.085639.

Błażejczyk A., Błażejczyk K., Baranowski J., Kuchcik M., 2017. Heat stress mortality and desired adaptation responses of healthcare system in Poland. Int J Biometeorol. doi 10.1007/s00484-017-1423-0.

Błażejczyk K., 2004. Bioklimatyczne uwarunkowania rekreacji i turystyki w Polsce (Bioclimatic principles of recreation and tourism in Poland). Prace Geograficzne IGiPZ PAN, 192.

Błażejczyk K., 2009. The consequences of the changes in global climate for human health. Papers on Global Change 16: 87-110.

Błażejczyk K., Baranowski J., Błażejczyk A., 2015. Wpływ klimatu na stan zdrowia w Polsce: stan aktualny oraz prognoza do 2100 roku (Influence of climate on health status in Po- land and projections to the year 2100). Wyd. Akademickie SEDNO, Warszawa.

Błażejczyk K., Baranowski J., Pisarczyk S., Szpot M., 2000. Influence of the human heat balance on respiratory and circulatory diseases. In: de Dear R.J., Kalma J.D., Oke T.R., Auliciems A. (eds.) Biometeorology and urban climatology at the turn of millennium, Selected papers from the Conference ICB-ICUC'99 (Sydney, 8-12 Nov. 1999), WMO, Genewa: 107-111.

Błażejczyk K., Błażejczyk A., 2012a. Changes in UV radiation intensity and their possible impact on skin cancer in Poland. Geographia Polonica 85, 2: 57-64.

Błażejczyk K., Błażejczyk A., 2012b. Środowiskowe i klimatyczne uwarunkowania zatruć pokarmowych - stan aktualny i prognoza do roku 2100 (Environmental and climatic conditions of food poisoning - current state and projections to the year 21000). In: Kantowicz E., Roge-Wiśniewska M. (eds.), Cywilizacja a środowisko - wyzwania i dylematy. Wydział Geografii i Studiów Regionalnych UW, Warszawa: 55-65.

Błażejczyk K., McGregor G., 2008. Mortality in European cities and its relations to biothermal conditions. In: Klysik K., Wibig J., Fortuniak K. (eds.), Klimat i bioklimat miast, Wydawnictwo Uniwersytetu Łódzkiego: 313-324.

Błażejczyk K., Piotrowicz K., Kuchcik M., Myszkowska D., Skotak K., Kunert A., Idzikowska D., 2011. Ocena skutków możliwych zmian klimatu dla zdrowia człowieka, cz. 1 (Assessment of possible climate change risks for human health, part 1). Raport dla Instytutu Ochrony Środowiska - PIB w ramach projektu pn. „Opracowanie i wdrożenie Strategicznego Planu Adaptacji dla sektorów i obszarów wrażliwych na zmiany klimatu - KLIMADA", Warszawa.

Błażejczyk K., Tokura H., Bortkiewicz A., Kato M., Szymczak W., 1999. Thermoregulatory and circulatory reactions in subjects exposed to the sun and wearing white and black clothing. In: Hodgdon J.A., Heaney J.H., Buono M.J. (eds.), Environmental Ergonomics VIII. International Series on Environmental Ergonomics, 1, Selected Papers from the 8th International Conference on Environmental Ergonomics, San Diego, California, USA, 18-23 Oct. 1998, Naval Health Research Centre, San Diego State University: 177-181.

Braks M., van Ginkel R., Wint W., Sedda L., Sprong H., 2014. Climate Change and Public Health Policy: Translating the Science. Int J Environ Res Public Health 11: 13-29. doi 10.3390/ijerph110100013

Confalonieri U., Menne B., Akhtar R., Ebi K.L., Hauengue M., Kovats R.S., Revich B., Woodward A., 2007. Human health. Climate Change 2007: Impacts, adaptation and vulnerability. Contribution of Working Group II to the Fourth Assessment Report of the Intergovernmental Panel on Climate Change, Parry M.L., Canziani O.F., Palutikof J.P., van der Linden P.J., Hanson C.E. (eds.), Cambridge University Press, Cambridge, UK: 391-431.

d'Ippoliti D., Michelozzi P., Marino C., de'Donato F., Menne B., Katsouyanni K., Kirchmayer U., Analitis A., Medina-Ramón M., Paldy A., Atkinson R., Kovats S., Bisanti L., Schneider A., Lefranc A., Iñiguez C., Perucci A., 2010. The impact of heat waves on mortality in 9 European cities: results from the EuroHEAT project. Environmental Health 9: 37.

Dessai S., 2002. Heat stress and mortality in Lisbon. Part I. Model Construction and Validation. Int J Biometeorol 47: 6-12. 
Diaz J., Linares C., Tobias A., 2006. Impact of extreme temperatures on daily mortality in Madrid (Spain) among the 45-64 age-group. Int J Biometeorol 50: 342-348.

Donaldson G.C., Keatinge W.R., 1997. Early increases in ischaemic heart disease mortality dissociated from, and later changes associated with, respiratory mortality, after cold weather in southeast England. J Epidemiol Comm Health 51: 643648.

Ebi K., 2008. Healthy people 2100: modelling population health impacts of climate change. Climatic Change 88: 5-19. doi 10.1007/s10584-006-9233-0.

Ebi K., 2015. Health in the new scenarios for climate change research. Int J Environm Res Publ Health 2014, 11: 30-46. doi 10.3390/ijerph110100030.

Eng H., Mercer J.,1998. Seasonal variations in mortality caused by cardiovascular diseases in Norway and Ireland. J Cardiovasc Risk 5: 89-95.

Eurowinter Group, 1997. Cold exposure and winter mortality from ischemic heart disease, cerebrovascular disease, respiratory disease, and all causes in warm and cold regions of Europe. Lancet 349: 1341-1346.

Fers J.P., 1995. Crises d'épilepsie et facteurs météorologiques dans le Finistère (Epilepsy crises and meteorological facts in Finistere). Climat et Santé 13: 57-74.

Gosling S.N., McGregor G.R., Páldy A., 2007. Climate change and heat related mortality in six cities Part 1: model construction and validation. Int J Biometeorol 51: 525-540.

Gosling S.N., McGregor G.R., Lowe J.A., 2009. Climate change and heat-related mortality in six cities. Part 2: climate model evaluation and projected impacts from changes in the mean and variability of temperature with climate change. Int J Biometeorol 53: 31-51.

Grillakis M.G., Koutroulis A.G., Tsanis J.K., 2016. The $2^{\circ} \mathrm{C}$ global warming effect on summer European tourism through different indices. Int J Biometeorol 60: 1205-1215. doi 10.1007/s00484-015-1115-6.

Gyllerup S., 1998. Cold climate and regional variation in coronary mortality in Sweden. In: Holmér I., Kuklane K. (eds.), Problems with cold work, Arbete och hälsa 18: 197-200.

Haines A., Kovats R.S., Campbell-Lendrum D., Corvalan C., 2006. Climate change and human health: Impacts, vulnerability and public health. Public Health 120: 585-596.

Huszcza A., 1951. Ciśnienie atmosferyczne $i$ jego dziatanie na ustrój (Air pressure and its impact on man), PZWL, Warszawa.

Improving public health responses to extreme weather/heat-waves - EuroHEAT. Technical report, 2009. WHO Regional Office for Europe, Copenhagen, Denmark.

Jendritzky G., 1995. Human health and atmospheric environment, in: Report from the meeting of experts on climate, tourism and human health, WMO/TD, No. 682.

Kalkstein L.S., 1998. Climate and human mortality: relationships and mitigating measures. Advances in Bioclimatology 5: 161-177.

Keatinge W.R., 2002. Winter mortality and its causes. Int J Circumpolar Health 61: 292-299.

Keatinge W.R., Donaldson G.C., 1998. Differences in cold exposures associated with excess winter mortality. In: Holmér I., Kuklane K. (eds.), Problems with cold work, Arbete och hälsa 18: 210-215.

Kiewra D., Dobracki W., Lonc E., Dobracka B., 2004. Ekspozycja na ukłucia przez kleszcze a występowanie rumienia wędrującego u pacjentów z boreliozą z Lyme na terenie Dolnego Sląska (Exposeure to ticks beets and
Lyme boreliosis at Lower-silesian region). Przeglad Epidemiologiczny 58: 281-288.

Kovats R.S., Edwards S.J., Hajat S., Armstrong B.G., Ebi K.L., 2004. The effect of temperature on food poisoning: a time-series analysis of salmonellosis in ten European countries. Epidemiology and Infection 132: 443-453.

Kozłowska-Szczęsna T., Krawczyk B., Kuchcik M., 2004. Wptyw środowiska atmosferycznego na zdrowie i samopoczucie cztowieka (Influence of the atmosphere on human health and wellbeing). IGiPZ PAN, Monografie 4, Warszawa.

Kuchcik M., 1998. Influence of atmospheric conditions on traffic accidents. The case of Radom. Miscellanea Geographica 8: 141-147.

Kuchcik M., 2001. Mortality in Warsaw: is there any connection with weather and air pollution? Geographia Polonica 74(1): 29-45.

Kuchcik M., 2006. Fale upałów w Polsce w latach 1993-2002 (Heat waves in Poland in the years 1993-2002). Przeglad Geograficzny 78(3): 397-412.

Kuchcik M., Błażejczyk K., 2001. Wpływ warunków pogodowych na zachorowalność i umieralność mieszkańców Warszawy (Influence of weather conditions on mortality and morbidity in Warsaw). In: Krawczyk B., Węcławowicz G. (eds.) Badania środowiska fizycznogeograficznego w aglomeracji warszawskiej. Prace Geograficzne 180: 71-87.

Laaidi M., Laaidi K., Besancenot J-P., 2006. Temperature-related mortality in France, a comparison between regions with different climates from the perspective of global warming. Int J Biometeorol 51: 145-153.

Laschewski G., Jendritzky G., 2002. Effects of the thermal environment on human health: an investigation of 30 years of daily mortality data from SW Germany. Climate Research 21: 91-103.

Lindgren E., Jaenson T., 2006. Lyme boreliosis in Europe: influences of climate and climate change, epidemiology, ecology and adaptation measures. WHO Regional Office for Europe, Copenhagen, Denmark.

Lityńska Z., Łapeta B., Wolska H., 2001. Index UV a człowiek (UV Index and man). IMGW, Warszawa.

Lucas R., McMichael T., Smith W., Armstrong B., 2006. Solar ultraviolet radiation, global burden of disease from solar ultraviolet radiation. Environmental Burden of Disease Series, No. 13, WHO, Public Health and the Environment, Geneva.

Małolepszy J., 1996. Choroby alergiczne i astma (Alergic diseases and astma). Volumed, Wrocław.

Matzarakis A., Mayer H., 1991. The extreme heat wave in Athens in July 1987 from the point of view of Human Biometeorology. Atmosph Environm 25B: 203-211.

Mączyński B., 1972. Warunki pogody - czas reakcji prostej i wypadki drogowe $\mathrm{w}$ Wielkopolsce (Weather conditions - reaction time an road accidents). Balneologia Polska 17(1/2): 307-336.

McGregor G.R., 2001. The meteorological sensitivity of ischaemic heart disease mortality events in Birmingham. UK. Int J Biometeorol 45: 133-142.

Meehl, G.A., T.F. Stocker, W.D. Collins, P. Friedlingstein, A.T. Gaye, J.M. Gregory, A. Kitoh, R. Knutti, J.M. Murphy, A. Noda, S.C.B. Raper, I.G. Watterson, A.J. Weaver and Z.-C. Zhao, 2007. Global climate projections. In: Climate Change 2007: The physical science basis. Contribution of Working Group I to the Fourth Assessment Report of the Intergovernmental Panel on Climate Change, Solomon S., Qin D., Manning M., Chen Z., Marquis M., Averyt K.B., Tignor 
M., Miller H.L. (eds.). Cambridge University Press, Cambridge, United Kingdom and New York, NY, USA.

Michelozzi P., Accetta G., De Sario M., D’Ippoliti D., Marino C., Baccini M., Biggeri A., Anderson H.R., Katsouyanni K., Ballester F., Bisanti L., Cadum E., Forsberg B., Forastiere F., Goodman P.G., Hojs A., Kirchmayer U., Medina S., Paldy A., Schindler C., Sunyer J., Perucci C.A., McGregor G., Menne B., Kosatsky T., Analitis A., Kassomenos P., Atkinson R., Clancy L., Goodman P.G., Pekkanen J., Woityniak B., Jolliffe I., Jendritzky G., Błażejczyk K., Huth R., Cegnar T., Iniguez C., Monceau G., Kalkstein L.S., 2009. High Temperature and Hospitalizations for Cardiovascular and Respiratory Causes in 12 European Cities. Am J Resp Critl Care Med 179: 383-389.

Munich Re Group, 2005. Weather Catastrophes and Climate Change. Münchener Rückversicherung-Gesellschaft, Munich.

Nakićenović N., Alcamo J., Davis G., de Vries B., Fenhann J., Gaffin S., Gregory K., Griibler A., Jung T.Y., Kram T., La Rovere E.L., Michaelis L., Mori S., Morita T., Pepper W., Pitcher H., Price L., Riahi K., Roehrl A., Rogner H-H., Sankovski A., Schlesinger M., Shukla P., Smith S., Swart R., van Rooijen S, Victor N., DadiTodea D.A., 2000. Special report on emissions scenarios. A Special Report of Working Group III of the Intergovernmental Panel on Climate Change. Cambridge University Press.

Pappenberger F., Jendritzky G., Staiger H., Dutra E., di Giuseppe F., Richardson D.S., Cloke H.L., 2014. Global forecasting of thermal health hazards: the skill of probabilis- tic predictions of the Universal Thermal Climate Index (UTCI). Int J Biometeorol. doi 10.1007/s00484-014-0843-3.

Paterson J., Berry P., Ebi K., Varangu L., 2014. Health care facilities resilient to climate change impacts. Int J Environm Res and Public Health 11: 13097-13116.

Peternel R., Srnec L., Culig J., Zaninović K., Mitić B., Vukusić I., 2004. Athmospheric pollen season in Zagreb (Croatia) and its relationship with temperature and precipitation. Int J Biometeorol 48: 186-191.

Samoliński B., Sybilski A.J., Raciborski F., Tomaszewska A., Samel-Kowlaik P., Walkiewicz A., Lusawa A., Borowicz J., Gutowska-Ślesik J., Trzpil L., Marszałkowska J., Jakubik N., Krzych E., Komorowski J., Lipiec A., Gotlib T., Samolińska-Zawisza U., Hałat Z., 2009. Prevalence of rhinitis in Polish population according to the ECAP (Epidemiology of Allergic Disorders in Poland) study. Otolaryngologia Polska 63(4): 324-330.

Siuda K., 1993. Kleszcze (Acari: Ixodida) Polski. Część II. Systematyka i rozmieszczenie (Ticks of Poland - systematic and distribution). Monografie Parazytologiczne 12, PTP, Warszawa.

Skotak K., 2010. Klimat a ochrona zdrowia (Climate and health protection). In: Kęder R., Kawczyńska K., Graczyk I., Jankiewicz I. (eds.) Klimat a zdrowie. Polska Federacja Pacjentów Dialtransplant, Warszawa: 84-88.

Thompson D. R., Jurgen P. E., Tse Y.-Y., Hiorns R.W., 1996. Meteorological factors and the time of onset of chest pain in acute myocardial infarction. Int J Biometeorol 39(3): $116-120$. 